\title{
Real-Time Data and Flood Forecasting in Tagus Basin. A Case Study: Rosarito and El Burguillo Reservoirs from 8th to 12th March, 2018
}

\author{
Ignacio Menéndez Pidal ${ }^{1, * \mathbb{C}}$, José Antonio Hinojal Martín ${ }^{2}$, Justo Mora Alonso-Muñoyerro ${ }^{3}$ \\ and Eugenio Sanz Pérez ${ }^{1}$ \\ 1 Department of Engineering and Morphology of the Terrain, Civil Engineering Insitute, Polytechnic \\ University of Madrid, 28040 Madrid, Spain; eugenio.sanz@upm.es \\ 2 Tajo Hydrographic Confederation, 28011 Madrid, Spain; joseantonio.hinojal@chtajo.es \\ 3 Applied Geology Research Group, Polytechnic University of Madrid, 28040 Madrid, Spain; jmora@ciccp.es \\ * Correspondence: ignacio.menendezpidal@upm.es
}

Received: 27 December 2019; Accepted: 27 March 2020; Published: 1 April 2020

\begin{abstract}
The hydrological regime of the Iberian Peninsula is characterized by its extreme irregularity, including its propensity for periodic floods, which cause severe floods. The development of suitable cartographies and hydraulic models (HEC-RAS, IBER, etc.) allows for defining, with sufficient precision, the areas flooded by a determined return period, and for elaborating maps of danger and areas at risk of flooding, making it possible to adopt the corresponding preventive measures of spatial planning. These preventive measures do not avoid the need for contingent plans, such as the Civil Flooding Protection Plans. Many of the Peninsula's watercourses and rivers are regulated by reservoirs built to ensure water supply and to smooth floods by releasing water in extreme hydrological climates. Hydrological modeling tools (rain/run-off) and Decision Support Systems DSS have been developed for the optimal operation of these dams in flood situations. The objective of the article is to study and prove the effectiveness of the integrated data provision in real time, while the event occurs-a circumstance that was not possible from the limited available meteorological stations available from Official Weather Services. The development of the Automatic Hydrological Information System (SAIH) in the Spanish River Basin Authorities (Confederaciones Hidrográficas), which includes a dense network of thermo-pluviometric stations and rain-river flow gauges, has allowed for new perspectives in order to realize an effective forecast method of flows during episodes of extreme precipitation. In this article, we will describe the integration of a hydrological modeling system, developed by the Confederación Hidrográfica del Tajo (River Authority), to meet the described objectives; the results of this methodology are novel. This allows for the processing of the 15-minute data provided, including the simulation of the snow accumulation/melting processes and the forecast of inflows to the reservoir to help in the establishment of safeguards and preventive waterflow releases. Finally, the methodology described is shown in a real case of study at Rosarito and El Burguillo Reservoirs.
\end{abstract}

Keywords: flood forecasting; snow cover control; flood management; Tagus Basin

\section{Introduction}

Floods are natural phenomena that cause significant damage. In Spain, $61.7 \%$ of the indemnities paid by the Insurance Compensation Consortium for claims in the years 1971-2017 were due to floods [1]. Their impact on goods, people, and, in general, on the economy and the organization of society, are related to both the intensity and frequency of the events generated by these phenomena, and the degree of exposure of human activity to flood risk. While floods are natural phenomena, 
the progressive occupation and alteration of the territory, as well as the increasing magnitude and recurrence of floods, induced by climate change [2], have increased our vulnerability to them, raising international concern about their danger.

In Europe, a new regulatory framework was developed to deal with the situation, formalized by Directive 2007/60/EC of the European Parliament and of the Council of 23 October 2007, on the assessment and management of flood risks (transposed to the Spanish legal order by RD 903/2010), in order for member countries of the EU to prepare Flood Risk Assessment and Management Plans (FRMPs). The elaborations of the cartography corresponding to the hazard and risk maps are fundamental elements in establishing the objectives and measures to be adopted by the plan. These flood risk management plans should encompass all aspects of flood risk management, focusing on prevention, protection and preparedness, including flood forecasting procedures that reduce uncertainty when it occurs [3].

The preparation of the FRMPs does not exclude the need for other contingency plans, designed for those cases in which the previous prevention and protection measures cannot guarantee that certain extraordinary episodes affect people and property. They include the actions and measures to be adopted to reduce damages in these situations in which, despite the precautions anticipated, the episode is imminent and inevitable. The existence of Early Warning Systems must allow for the adequate forecasting of phenomenon of this magnitude occurring in a predictable time, making it possible to warn the population and to mobilize the means and resources established in the plan.

In Spain, these contingent plans are formalized through the Civil Protection Plans against the Risk of Floods (Agreement of the Council of Ministers of December 9, 1994 and the Basic Guideline for Planning of Civil Protection against the Risk of Floods) to which two early warning systems are incorporated: the meteorological alert and hydrological alert. The Prediction and Meteorological Surveillance System, in charge of AEMET (Spanish Meteorological Agency), communicates, to the corresponding Civil Protection Unit, the warnings concerning the forecasts of extraordinary events, in this case, rains that exceed a certain threshold.

With regard to the Hydrological Prediction and Surveillance System, this function is facilitated by the Hydrographic Confederations by providing the relevant information, for the purposes of flooding, provided by the SAIH, whose characteristics are described below. Among the data provided to Civil Protection, when the corresponding authority orders the implementation of the Plan, it includes data on the flows and water levels in certain sections of rivers, as well as the evolution of the volumes stored and the inputs/outputs of the reservoirs.

These Plans dedicate an important part to the management of critical situations of dams at risk of falling-out, establishing communication protocols with Civil Protection and warning the population, contained in their respective Emergency Plans.

In Spain, due to the number and volume of the same rain, the reservoirs play a very important role in the control and reduction in flood damage due to their storage capacity and smooth rolling effect during floods. However, the statistics indicate that a significant percentage of serious accidents [4] occur precisely during the events, when there are stress demands on its structure, and its stability conditions sub pressures and the operability of its mechanical elements (valves, spill gates, etc.) are extreme. Among these situations, the worst is when overtopping occurs, and is especially dangerous in the case of earth dams, meaning the structure will certainly be ruined and result in the generation of a flood wave that propagates downstream and generally has catastrophic effects.

Likewise, the existence of information systems capable of providing hydrometeorological data in real time and the availability of hydrological simulation models for forecasting inlet flows in reservoirs allows for the optimization of the operation of the reservoirs in order to minimize damage downstream of the dams, thus maintaining their structural safety. That is essential in a country, like Spain, where the irregularity of its hydrological regime has determined the existence of more than 1300 large dams. 


\section{Objectives}

Hydrological forecasting is especially interested in the headwaters of the rivers where precipitations are usually more intense, generating floods where propagation downstream can cause flooding on the banks. In general, this circumstance is singularly compromised at the end of spring, when it is necessary to ensure the storage of a sufficient volume of water for the next summer's irrigation campaign, in the middle of the river low season, which obliges the minimization in the guards of the dams.

In the Iberian Peninsula, many of them are located in mountainous areas (rivers in the Ebro, Duero, Tajo basins, etc.) where the presence of snow is hydrologically significant, so its modeling must reproduce the processes of accumulation/fusion of snow-a circumstance that does not meet the conventional applications commonly used in the SAIH environment. However, these areas have been studied through the study of Water Resources Assessment from the Snowing (ERHIN) [5], including the application of specific models. Its calibration was carried out using official meteorological data (precipitation and temperature, fundamentally) from the current State Meteorological Agency (AEMET) and flow rates from the Official Gauging Stations Network (ROEA)—achieving sufficiently adjusted results in the cases considered.

Obviously, the procedure followed to obtain these results, although valuable for learning and improving the rules of exploiting reservoirs, based on the analysis of their behavior in the face of historical flood events, is not valid as a predictive methodology. For these applications to be effective, it is necessary to supply data in real time, while the event occurs-a circumstance that was not possible due to the few available meteorological stations.

The objective pursued by the work described in this article is to develop a process that allows for the construction of hydrological forecasts of inlet flows in reservoirs located in mountainous areas of the Tagus Basin (Spain) in order to help establish shelters and preventive imbalances in dams during flood periods at risk of flooding.

The research to achieve the proposed objective consists of the coordinated application of the instruments available in the Tajo Hydrographic Confederation, adapting the hydrological modeling system of the ERHIN program for its continued operation, coupled with SAIH, as a source of data supply in real time. This allows for fifteen-minute data processing, including the simulation of snow accumulation/melting processes. Its systematic application on a daily basis, starting from the month of November of each hydrological year, reproduces the virtual construction of the snow cover, which allows the ERHIN-Tajo modeling system to ascertain the water reserves in the form of snow, which are potentially available for fusion and incorporation into ordinary water runoff.

This methodology has been successfully applied to forecast entrances into the Rosarito (Tiétar River) and El Burguillo (Alberche River) reservoirs, and help establish safeguards and preventive imbalances therein. For these purposes, the results of applying this methodology during the episode of heavy rains in March 2018 are shown below.

Additionally, the application of this methodology has contributed to a more rational and efficient use of the tools that are already available in the Hydrographic Confederation, with practically no additional investment. This process, extended to the rest of the Confederations where the necessary elements of the SAIH and ERHIN are operational, has been completely innovative in Spain, providing useful information for the improvement of the flood forecasting system.

\section{Available Means and Tools}

\subsection{The Automatic Hydrological Information System (SAIH) and the Program for the Evaluation of Resources} from Innivation (ERHIN)

In Spain, the then General Directorate of Hydraulic Works (now the General Directorate of Water) promoted, from 1982, the implementation of the Automatic Hydrological Information System (SAIH) [6] in the main peninsular hydrographic basins. It is a system for the provision of real time 
data, based on the capture, transmission and processing of the adopted values by the most significant hydrometeorological and hydraulic variables, at certain geographical points of the monitored river basins. In particular, the data are from their own network of:

- Automatic pluviometers and nivometers.

- Gauging stations in rivers, canals and impulsion systems.

- Reservoirs level, position of floodgates, evacuated flows (latter, spillways), which allow estimating other calculated data (reservoir volume, inputs, etc.).

- Complete and thermopluviometric weather stations.

- Telenivometers (Ebro, Tagus and Duero Basins).

These data are transmitted by HISPASAT satellite or by the radio network, which owns the system, to a central position in the corresponding Hydrographic Confederation, namely the River Authority, and other secondary management. Central headquarters manages the entire procedure of data processing, visualization and distribution, periodic reports, as well as the development of programs and applications for the management of hydraulic infrastructures, or, where appropriate, for the transmission of data to Civil Protection services and for advice to its Central Command Post of the plan when it is activated.

The data update is normally done every fifteen minutes, and it can be considered as a real time or quasi-real system due to temporal variation of the magnitudes of the physical variables involved (rain, temperature, etc.), hydrological (rainfall, runoff, and flow) and hydraulic processes (river propagation, etc.)

\subsection{Evaluation of Resources from Snow (ERHIN)}

However, the same General Directorate mentioned, pushed through, in 1986, the production of studies in the sub-basins of the Pyrenees watershed to the Ebro River to determine the Evaluation of Water Resources from Snow (ERHIN). The snow phenomenon produces a natural regulation of water resources, generating an accumulation of these at high levels to subsequently, in certain circumstances, proceed to their melting point through a complex process governed by various meteorological variables, among which are temperature, rain, radiation, humidity and wind speed. This circumstance means that a specific treatment is required for the quantification of nival resources, as well as the forecasting of their evolution over time and the corresponding flow contributions that come from their melting process. This specific treatment is not reproduced by the ordinary models of hydrological simulation. For this, a method was initially developed to correlate snow thickness and density measurements, taken from a steel pole network that was outspread in the Spanish Pyrenees, with flow data observed in the Official Gauging Stations Network (ROEA) of the Hydrographic Confederation of the Ebro and of the entrances to the downstream reservoirs [7] This resulted in the first simplified tool being used for the estimation of the volume of water stored in the form of snow.

Going deeper into its analysis, it was decided to adapt the methodology applied in other pre-existing models to the Spanish casuistry. For the treatment of the snow phenomenon, the SNOW-17 model of the North American National Weather Service was selected [8] — being implemented on a distributed model, in which discretization of the study area is allowed for its adaptation to the orography existing in the Peninsula and its climatic characteristics. Despite the numerous modern approaches dealing with hydrological models that are useful for flood prediction and flood frequency estimation, the complexity of the implementation for management purposes suggested work with a specific algorithm - which was constructed for this purpose-from the start, which was many years ago [9-12]. For modelling the flow of liquid water on the ground the calculation algorithm, which is the core of the hydrologic model called ASTER, was constructed [13]. The model uses a usual hydrological balance in each of the cells of the distributed model, which is similar to the one used by the CEQUEAU model developed by the National Institut de la Recherche Scientifique (INRS) of Canada [14]. 
This ASTER model has been used the most by water management agencies in Spain (Hydrographic Confederations), in the field of the ERHIN program, and is conceptually composed of the integration of a distributed rain-runoff model and a specific module to simulate the evolution of water storage simulating snow.

Progressively, these works were extended to other basins with similar characteristics. Finally, the areas of the Iberian Peninsula where the presence of snow turned out to be hydrologically significant were analyzed, identifying and delimiting the sub-basins of mountain headlands to be integrated into the ERHIN program. [15,16].

The ASTER hydrological model, initially developed in the Aragón basin and Yesa reservoir, was refined for the simulation of the main snow-capped basins leading to reservoirs, using, for the calibration of the same, the readings of the poles installed for the measurement of thicknesses and densities of snow and hydrological data, provided by the former National Institute of Meteorology (INM) — today the State Meteorological Agency (AEMET)_and the Official Network of Gauging Stations (ROEA) of the respective Hydrographic Confederations [17-19]

\section{Methodology}

As previously stated, the objective of the proposed methodology is to design and apply a process that allows for the construction of hydrological forecasts of inlet flows in reservoirs located in mountainous areas of the Tajo basin (Spain) in order to help establish preventive safeguards and imbalances in dams during flood periods in situations of flood risk. This would facilitate the optimization of the operation of reservoirs when snow processes upstream of their sites affect them.

The application of hydrological simulation models to predict flood hydrographs at the entrance of reservoirs is common. However in cases, such as those discussed, in which, due to its orographic and climatic characteristics, the watershed can store significant amounts of water as snow cover, in addition to the conventional runoff fraction generated by rainfall, it is necessary to consider the effect of melting or snow accumulation. This requires the use of distributed models, such as ASTER, that contain an accumulation/melting subroutine that determines, in each cell, whether solid rainfall will be received or if the conditions for the liquefaction of part or all of the snow cover are logged.

The application of these types of models as tools to help decision-making in the management of a reservoir in a normal or exceptional hydrological situation (floods) requires at least:

- Having information in real time regarding the main hydrometeorological variables.

- Knowing the characteristics of the snow cover: distribution, thickness, and equivalent in water at all times.

To solve this issue, the following methodology was adopted, as shown in Figure 1, and was applied to the Tagus basin:

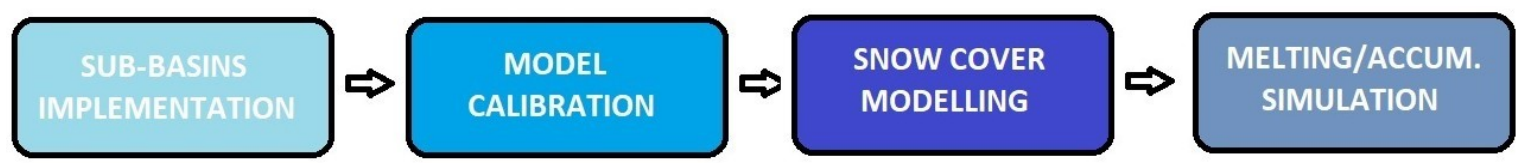

Figure 1. Methodological scheme applied to the Tagus Basin.

\subsection{ASTER Tagus Sub-basins Implementation}

The ASTER model was implemented in all the sub-basins identified in the ERHIN program, as headers, where the presence of snow is hydrologically significant. Among them, it was implemented in the ERHIN zones of the Tagus basin-its geographical location can be seen in Figure 2 and Table 1. 


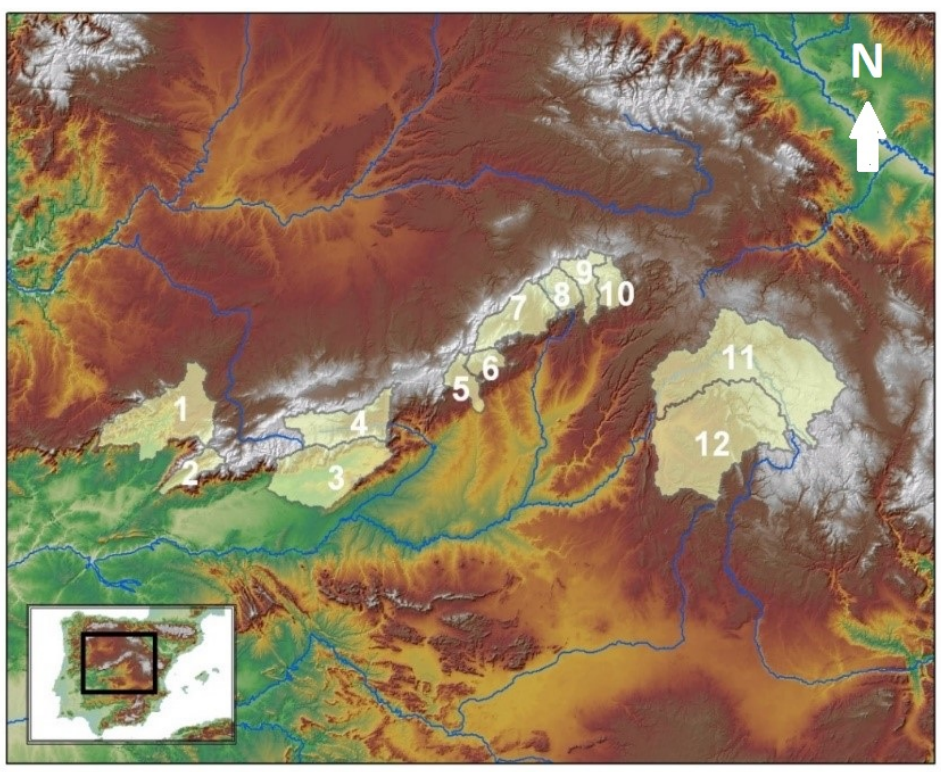

Figure 2. Headland sub-basins included in the ERHIN program in the Tagus basin.

Table 1. ERHIN zones in the Tagus Basin, where ASTER is operational.

\begin{tabular}{llc}
\hline \multicolumn{1}{c}{ Basin } & \multicolumn{1}{c}{ Control Point } & Surface $\mathbf{( k m}^{\mathbf{2}} \mathbf{~}$ \\
\hline 1. Alagón & Gabriel y Galán Reservoir & $1.841,60$ \\
2. Jerte & Plasencia & 367,60 \\
3. Tiétar & Rosarito Reservoir & $1.730,30$ \\
4. Alberche & Burguillo Resevoir & $1.052,70$ \\
5. Guadarrama & Picotejo & 357,20 \\
6: Manzanares & Santillana Reservoir & 247,10 \\
7. Lozoya & El Atazar Reservoir & 925,00 \\
8. Jarama & El Vado Reservoir & 378,00 \\
9. Sorbe & Beleña Reservoir & 475,60 \\
10. Bornova & Alcorlo Reservoir & 362,30 \\
11. Alto Tajo & Entrepeñas Reservoir & $3.825,40$ \\
12. Guadiela & Buendía Reservoir & $3.355,70$ \\
\hline
\end{tabular}

\subsection{Model Calibration}

Calibration of the model with the rainfall and temperature data supplied by the SAIH and was adjusted to the system flow control points, since the data from AEMET and the official ROEA capacity network are not available in real time. ASTER supports different extrapolation curves of the temperature data recorded by the SAIH stations in order to estimate their value in each cell, taking into account the meteorological situation and the corresponding thermal gradients. Figure 3 shows the geographical location of the SAIH data supply points. Among them, the river gaps and reservoirs serve to compare the flow values measured and supplied in quasi-real time (every 15 minutes) with those calculated by the model for adjustment and calibration. 


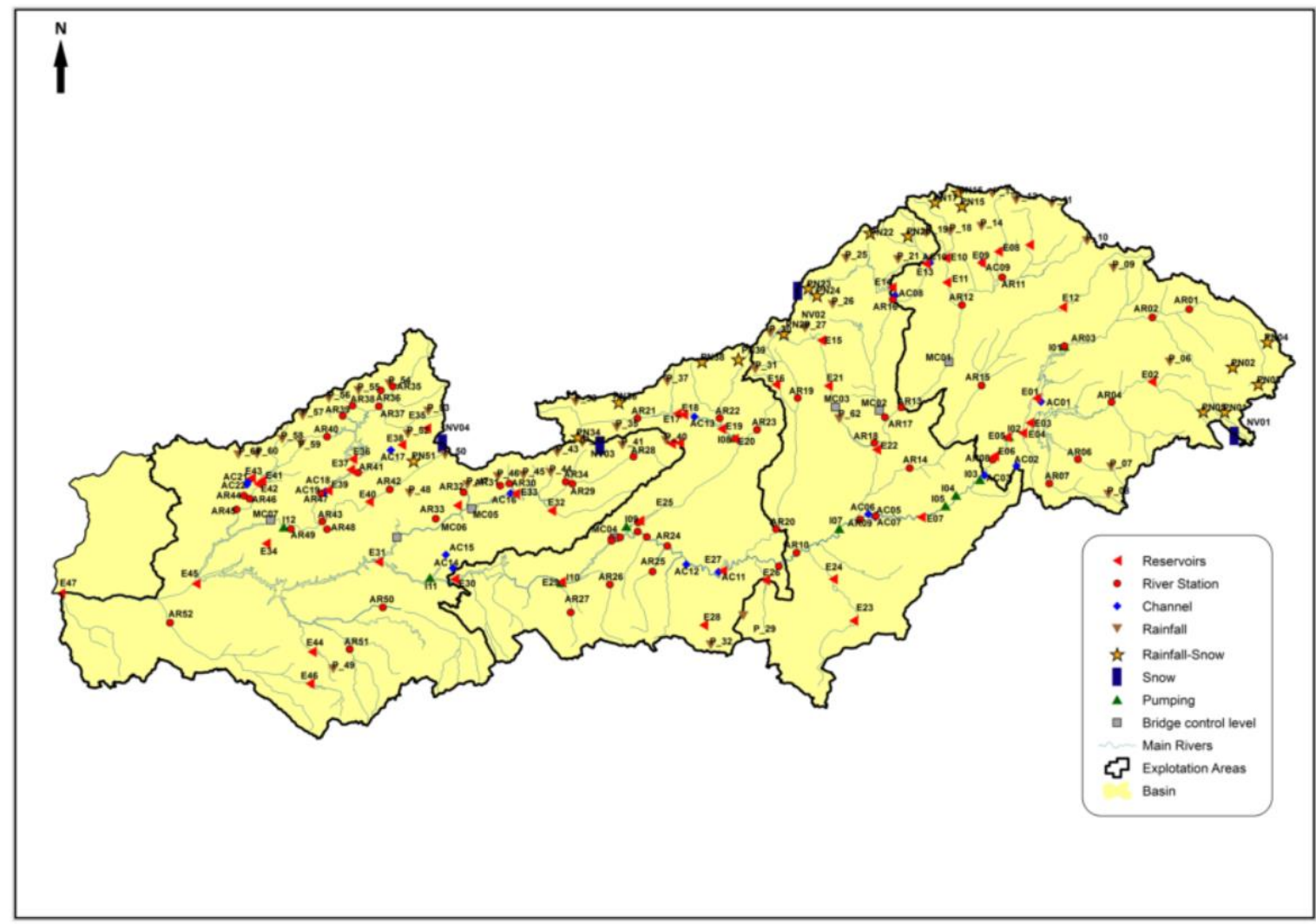

Figure 3. SAIH network control points-Tagus Basin.

The model, fed daily (during the months November to June) with the data provided by the SAIH meteorological stations, allows for the virtual construction of the snow cover. Its thickness and density are contrasted with field measurements (usually twice a year). The extent of snow cover is estimated by the model using cells, in which the existence of stored snow is determined, and is compared with satellite observations (Figure 4)

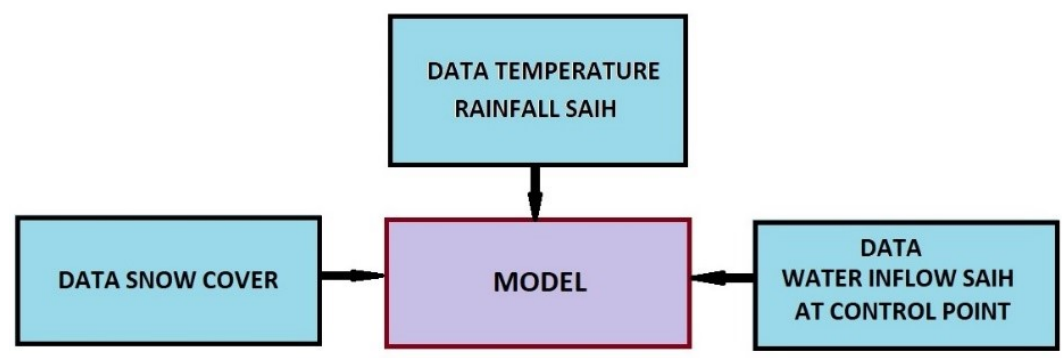

Figure 4. Calibration of the ASTER model with data from the SAIH network control points.

More recently, the ECMW (European Center for Medium-Range Weather Forecasts) numerical prediction model facilitates seven-day snow accumulation forecasts, allowing an additional precision in the results of the evolution of the snow cover obtained by ASTER

\subsection{Snow Cover Modelling}

The periodic (daily or weekly) and systematic application of the model from the beginning of November is displayed in order to reproduce the generation of the snow cover, represented by the snow storage conditions in each cell. Periodically, the gap of the snow cover, obtained with ASTER, is controlled against its real limits observed by remote sensing (TERRA/AQUA MODIS sensor images), and when possible, by collecting in situ snow thicknesses and densities. 
The model is able to determine the cells in which the liquefaction conditions are reached and activate the corresponding simulation module of the melting process, but it needs to ascertain whether there was actually snow previously stored in it, and if applicable, the thickness and equivalence in water. These data and the month in which the snow storage process can start from certain levels are known thanks to the historical monitoring of the evolution of the mantle that has been carried out every year since November. The numerical results are reflected in the corresponding monitoring graphs for each zone or sub-basin, obtaining, by aggregation, the evolution of the total snow accumulated in the whole of the basin. See Figures 5 and 6.

\begin{tabular}{|c|c|c|c|c|c|c|c|}
\hline \multicolumn{4}{|c|}{ River Basin } & \multicolumn{4}{|c|}{$\left({ }^{*}\right) 02 / 23 / 2014$ State } \\
\hline \multirow{2}{*}{ Order } & \multirow{2}{*}{ Sistem } & \multirow{2}{*}{ Code } & \multirow{2}{*}{ Control Point } & Modelled surface & VAFN & Contribution & Snow Reserves \\
\hline & & & & $\left(\mathrm{km}^{2}\right)$ & $\left(\mathrm{hm}^{3}\right)$ & $\left(\mathrm{hm}^{3}\right)$ & \\
\hline 1 & \multirow{12}{*}{$\begin{array}{l}\text { Central } \\
\text { Sistem }\end{array}$} & D.II.6.1/I & Alagón at Gabriel and Galán & $1.848,2$ & 7,2 & 723,5 & Very high \\
\hline 2 & & D.II.6.2/I & Jerte at Plasencia & 370,0 & 3,2 & 175,7 & Low \\
\hline 3 & & D.II.5/I & Tietar at E. de Rosarito & $1.743,2$ & 12,8 & 501,8 & 5 year Maximum \\
\hline 4 & & D.II.4/I & Alberche at the Burguillo & $1.052,7$ & 19,0 & 130,6 & High \\
\hline 5 & & D.II.3/I & Guadarrama at Picotejo & 355,9 & 2,3 & 33,8 & 5 year Maximum \\
\hline 6 & & D.II.2.3/I & Manzanares at Santillana & 247,1 & 7,8 & 46,1 & 5 year Maximum \\
\hline 7 & & D.II.2,2.B/I & Lozoya at the Atazar & 925,0 & 30,4 & 180,4 & 5 year Maximum \\
\hline 8 & & D.II.2.2.A/I & Jarama at the Vado & 378,0 & 7,3 & 88,0 & Very high \\
\hline 9 & & D.II.2.1.B/I & Sorbe at Beleña & 475,6 & 0,0 & 81,4 & Normal \\
\hline 10 & & D.II.2.1.A/I & Bornova at Alcorló & 362,3 & 0,0 & 50,9 & Normal \\
\hline 11 & & D.II.1.1/I & Alto Tajo at Entrepeñas & $3.825,6$ & 0,0 & 162,5 & Low \\
\hline 12 & & D.II.1.2/I & Guadiela at Buendia & $3.355,8$ & 0,0 & 161,8 & Normal \\
\hline & & & Total: & $14.939,4$ & 90,0 & 2336,6 & \\
\hline
\end{tabular}

VAFN: Water volume in snow form

Figure 5. Example of monthly snow report (ERHIN) in the Tagus Basin (Tagus Hydrographic Confederation).

Report date: 02/23/2014

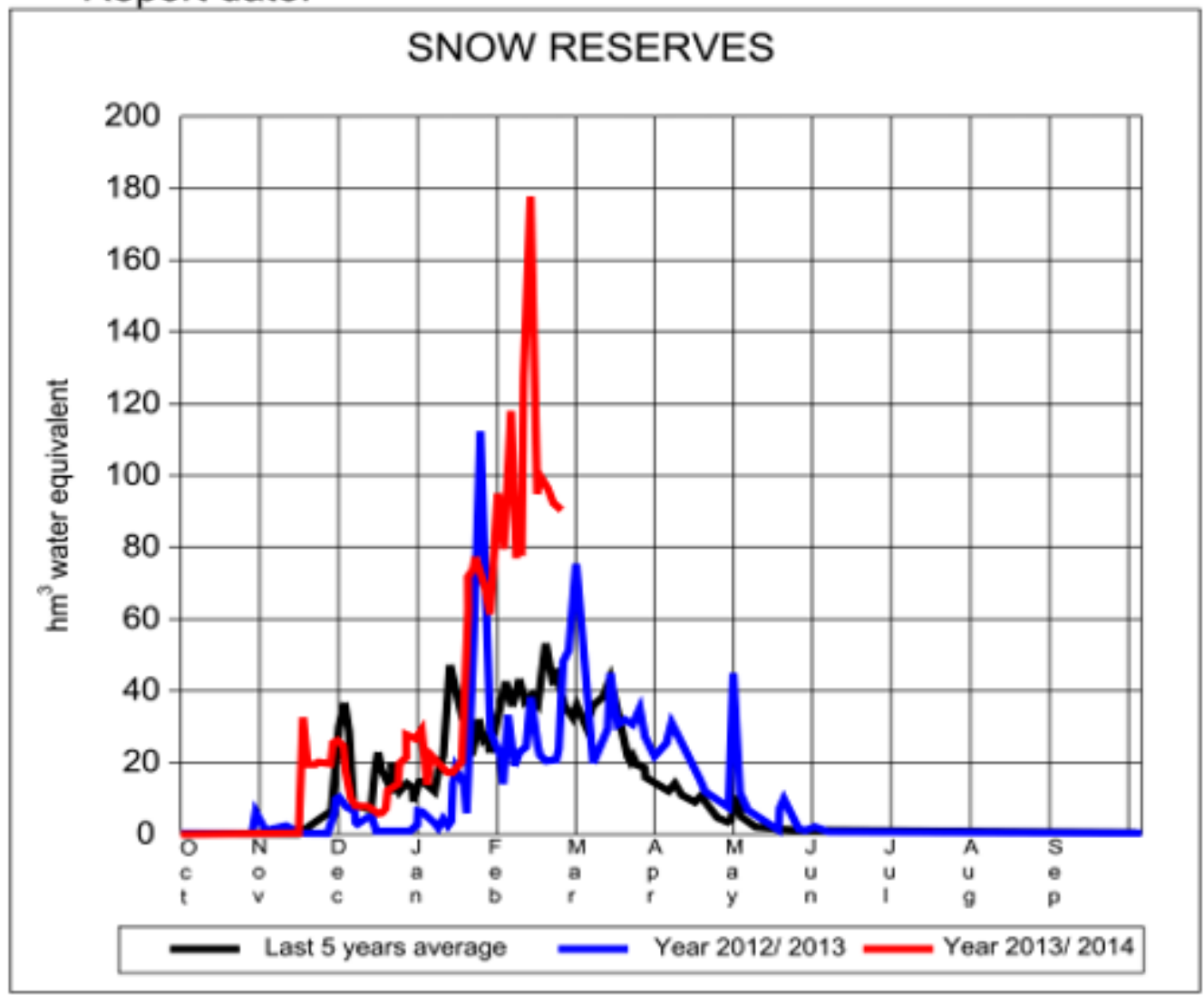

Figure 6. Graphic type of monitoring of snow reserves in the ERHIN area of the Tagus basin (Tagus Hydrographic Confederation). 


\subsection{Melting and Accumulation Snow Cover Simulation}

Finally, there is a hydrological model that works with a subroutine that allows for the simulation of snow accumulation/melting processes in the mountainous headwaters of the rivers that flow to the reservoir in operation, and with a system for providing basic data (temperature and rainfall), in real time, on the information at any time about the stored snow and its geographical distribution. Therefore, it is a system capable of automatically recording rainfall over the basin, upstream of the reservoir, and anticipating the inflow generated by the runoff, and where appropriate, by the melting of the snow cover.

In addition, the system is fed with the data corresponding to the weather forecasts for several days ( 3 to 7 days). This significantly extends the time available to carry out the necessary preventive actions, establishing a safety margin in line with the forecasts of incoming flows that allow for the management of the reservoir in the case of floods, see Figure 7. Therefore:

- Minimizing the peak value of the outflow, and therefore, downstream damage.

- Maximizing the volume of water stored and the guarantee of supply, avoiding excesses in preventative release cases.

- Ensuring the safety of hydraulic infrastructure by reducing the chances of overflow by crowning (overtopping).

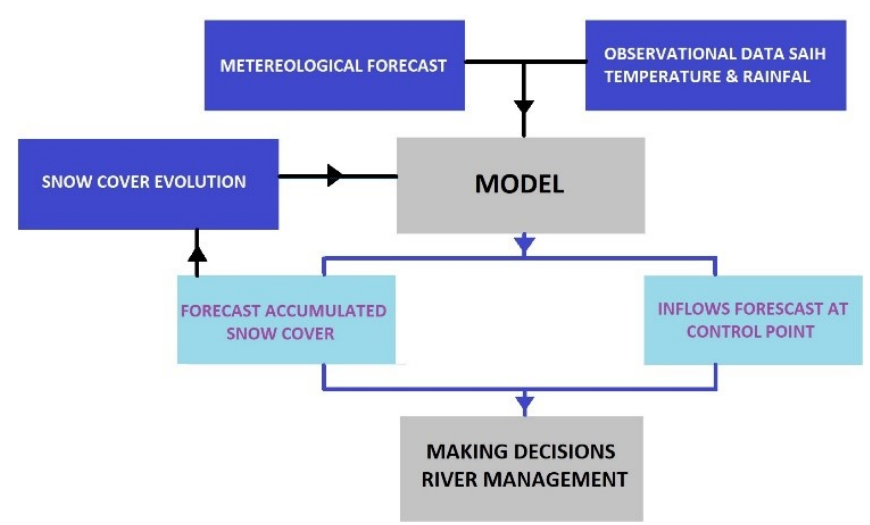

Figure 7. Scheme of operation of the model in real time.

The ASTER-SAIH system aims to obtain the maximum performance from the ASTER application, taking as input the data provided in real time by the SAIH. The system execution requires the observed thermopluviometric values available at that time at SAIH stations as input data. If required, it can propose forecast scenarios with different meteorological hypotheses, adjusting the model with real data of flows from SAIH and real data snow cover.

The data obtained, as a result of the forecast, are the inflow flows to the reservoir and the equivalent volume of water, stored as snow in the watershed. These are very helpful values in decision making (reservoir management).

\section{Results: Rosarito and El Burguillo Reservoirs Practical Cases}

The actions described in the previous section need to be completed in order to develop the proposed methodology and to make it fully operational-this has been applied by the technical services of the Tagus Hydrographic Confederation under different flood episodes. Some recent results are described below; specifically, those corresponding to the period between 8th and 12th March, 2018, during the storm caused by the "Felix" cyclone. At that time, a progressive and intense cyclogenesis swept the Iberian Peninsula from West to East, and involved the Canary Islands. This episode caused the activation of Civil Protection Plans in all the Spanish Autonomous Communities. In the first few days, there was intense rainfall throughout the Spanish territory. 
In the Tagus basin, the most important rains were recorded on 9th and 10th March, while the floods in the main rivers, as well as the flood control in the reservoirs, were extended until 12th March.

The monitoring of the meteorological forecasts that are continuously received in the SAIH room board at the Hydrographic Confederation, allowed for the launching of the Reservoir Release Standing Committee. For this reason, the first AEMET rainfall forecasts were developed at the scale of the Tagus basin, see Figure 8.

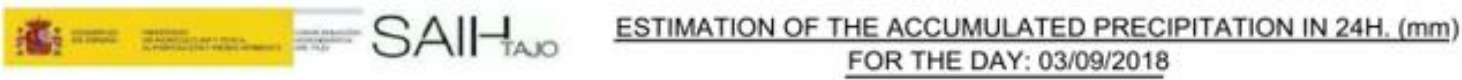

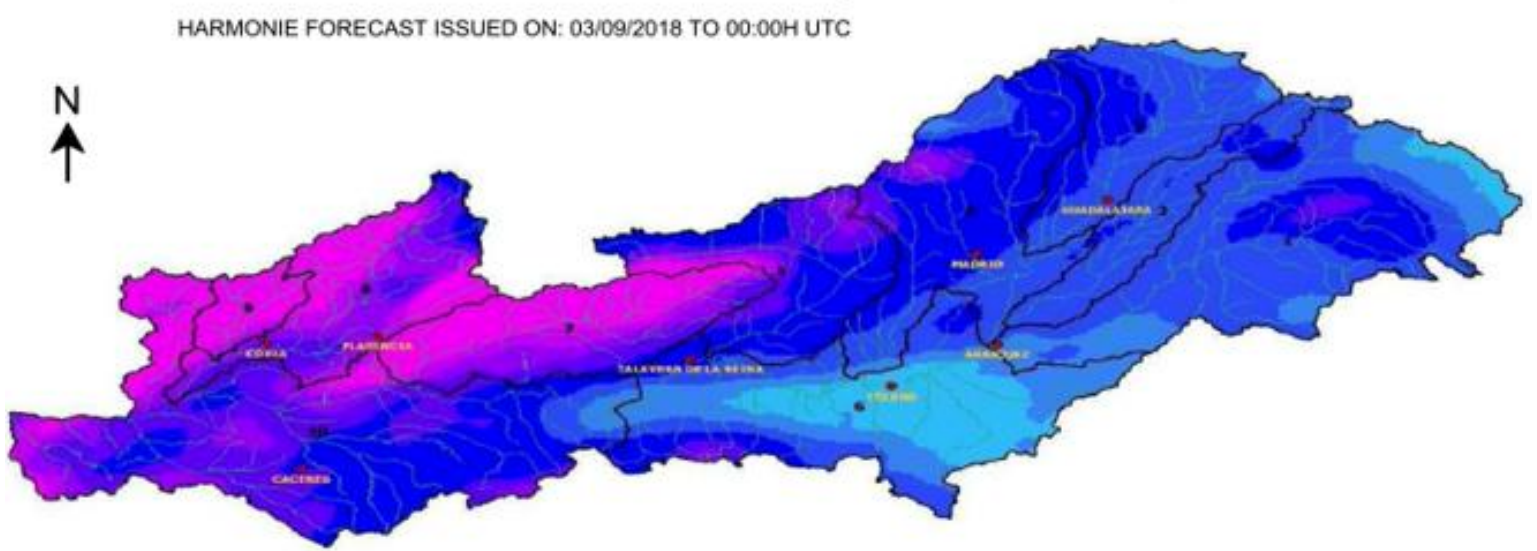
Estimated acoumulated
raintall in 24 hours. $(\mathrm{mm})$

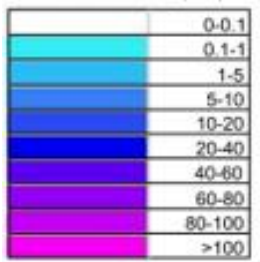

\begin{tabular}{|c|c|c|c|c|c|}
\hline \multicolumn{6}{|c|}{ TANO RIVER BASIN } \\
\hline COOE & WATER AREAS & P medium (mm) & COOE & WATER AREAS & P medium (mm) \\
\hline 01 & RIVER BEGINS & 7.9 & 06 & LEFT BANK & 5.6 \\
\hline 02 & TAUUNA & 8.1 & 07 & TIETAR & 55.7 \\
\hline 03 & HENARES & 8.7 & 08 & ALAOON & 43.4 \\
\hline 04 & GUADALAJARA - JARAMA & 13.5 & 09 & ARRAGO & 68.7 \\
\hline 05 & ALBERCHE & 21.5 & 10 & BAJO TANO & 26.1 \\
\hline
\end{tabular}

Figure 8. Rainfall forecasts on the day of the starting episode.

These predictions show the special intensity of the episode in the western part of the basin, particularly in the river basins of the Árrago River, Alagón River and Tiétar River, and less intensively, in the Alberche River. On 10th March, different yellow warnings were received (referred to as a three steps scale: red, yellow, and green) from the AEMET, State Meteorological Agency, which affected the Autonomous Communities of Madrid and Castilla la Mancha, and alerted to them heavy rainfalls, snowfalls and winds, see Figure 8.

The Tiétar basin deserves special attention since it is located the Rosarito reservoir (Figure 9), and its operation is uniquely delicate. With only $8190 \mathrm{hm}^{3}$ of capacity compared to an average contribution of $800 \mathrm{hm}^{3}$, it must meet a demand of $240 \mathrm{hm}^{3}$, the majority for irrigation, concentrated in the months between April and September. The altitude of the Rosarito dam is $283.7 \mathrm{~m}$ (minimum level) and it is located at the bottom of the southern part of Sierra de Gredos (2500 m maximum altitude), where the annual average rainfall regime, at its summits, often exceeds $2000 \mathrm{~mm} /$ year. The flow contributions of its watershed are characterized by a steep average slope and a short concentration period. Therefore, there is a high risk of sudden floods, with very high peak flow values, in which flows from the snow melting can contribute significantly. Therefore, anticipating the forecast of the flood hydrograph, including the additional fraction of snow melting, is extraordinarily important. 


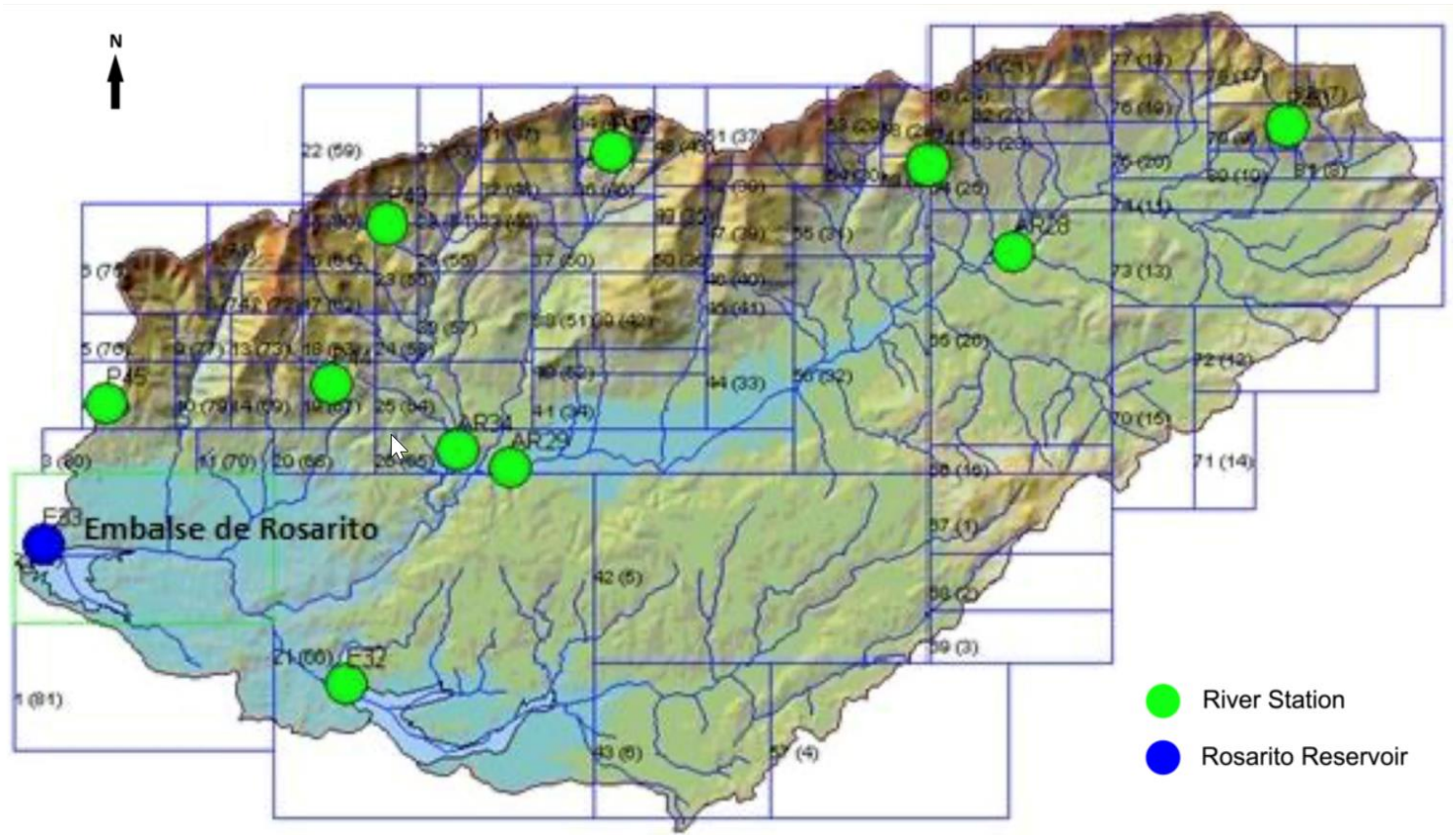

Figure 9. Location of the Rosarito Reservoir in the lower part of the Tiétar Basin.

Figure 10 shows the results that correspond to the forecast of flows and the volume of water stored in the form of snow in the period between 9th and 18th March, 2018. In the first and second part of the graph, the real values (blue) of temperature and precipitation appear on the previous dates (provided by SAIH), and these parameters forecasted by AEMET(green). Between them, the more unfavourable meteorological values were chosen and correspond to the most probable and expected precipitation and temperature values.

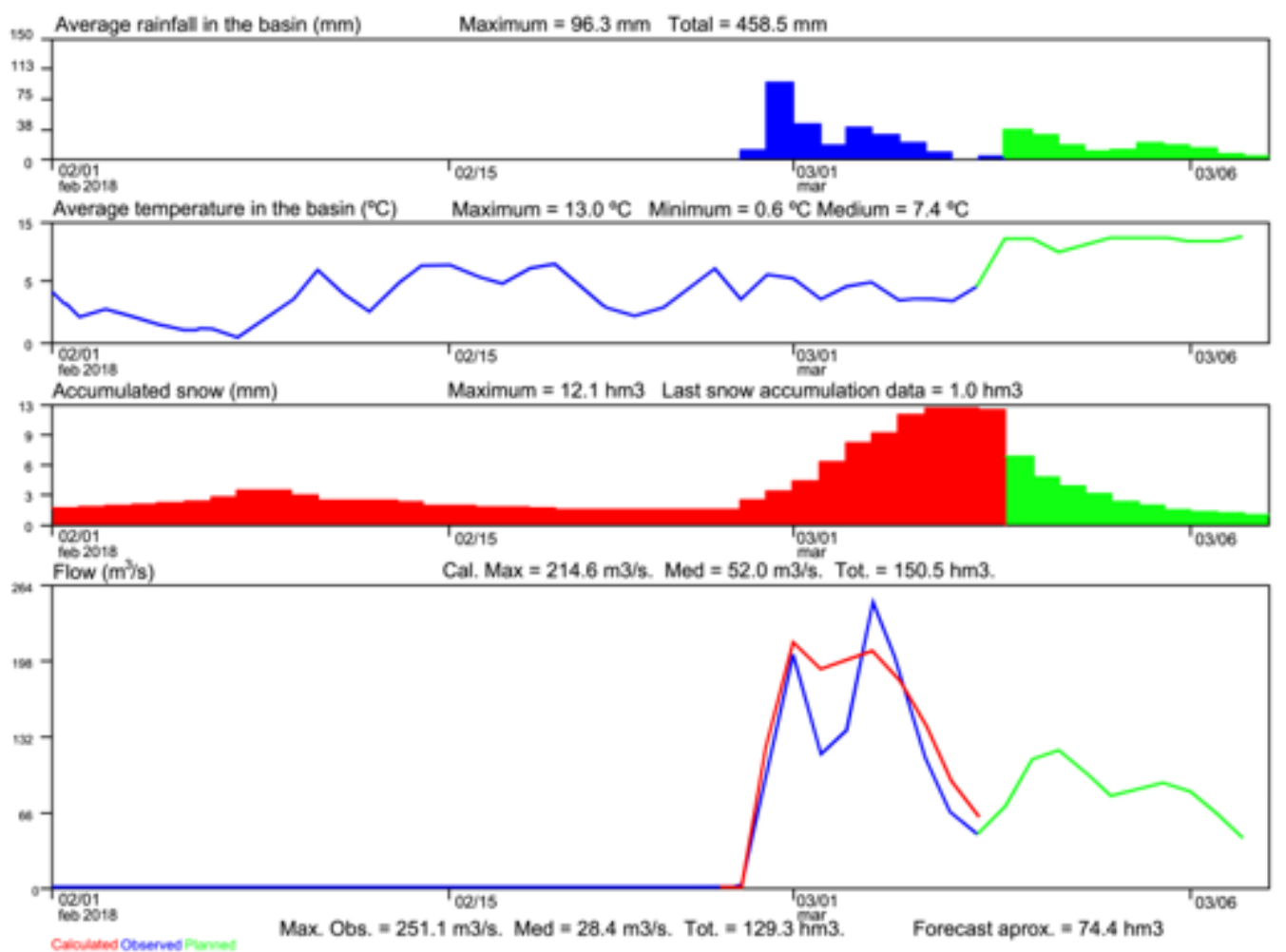

Figure 10. Flow forecast graph (green) in the Rosarito reservoir, with the AEMET (most unfavorable) temperature and rainfall predictions. 
In the third part, the volumes of water that accumulated in the form of snow-estimated by ASTER-ERHIN (red) on the date preceding the beginning of the episode (9th March, 2018)—are shown. It is observed how the storm, one day before, contributed a notable increase in snow storage, with potential fusion, and added to the runoff due to the foreseeable rains, which added an additional risk of flows. Finally, in green, the total snow values accumulated during that period of time which reflect a clear melting process of almost $11 \mathrm{hm}^{3}$, due to the expected increase in temperature

Finally, in the fourth part, the red line corresponds to the inlet flows to the reservoir, calculated by the ASTER-ERHIN model, with the precipitation and temperature data provided by the SAIH; the blue line shows the measured input values (input/output balance/volume increase) by SAIH and the green line represents the flow forecast provided by the model with the prediction of temperatures and rainfall delivered by AEMET.

The calculated values of the Volume $\left(\mathrm{hm}^{3}\right)$ of Water in Snow (VAFN), the predicted values (ASTER-ERHIN) of average daily and cumulative flows $\left(\mathrm{m}^{3} / \mathrm{s}\right)$ into the Rosarito reservoir, with AEMET (most unfavourable) predictions of temperature and rain and its accumulated volume inflow $\left(\mathrm{hm}^{3}\right)$, are shown in Table 2.

Table 2. Expected values of average daily flows entering the Rosarito reservoir from AEMET (most unfavourable) temperature and rainfall predictions. Between 8 March, 2018 and 18 March, 2018, near $11 \mathrm{~m}^{3}$, are coming from snowmelt.

\begin{tabular}{|c|c|c|c|}
\hline $\begin{array}{c}\text { Date } \\
\text { (at 00:00 h) }\end{array}$ & $\begin{array}{l}\text { Snow Water Volume } \\
\qquad\left(\mathrm{hm}^{3}\right)\end{array}$ & $\begin{array}{l}\text { Flow } \\
\left(\mathrm{m}^{3} / \mathrm{s}\right)\end{array}$ & $\begin{array}{l}\text { Accumulated Volume Inflow } \\
\qquad\left(\mathrm{hm}^{3}\right)\end{array}$ \\
\hline 8 March 2018 & 11.93 & & \\
\hline 9 March 2018 & 7.13 & 71.92 & 6.21 \\
\hline 10 March 2018 & 4.83 & 112.14 & 15.90 \\
\hline 11 March 2018 & 3.88 & 120.95 & 26.35 \\
\hline 12 March 2018 & 3.12 & 101.60 & 35.13 \\
\hline 13 March 2018 & 2.40 & 81.60 & 42.18 \\
\hline 14 March 2018 & 1.85 & 86.77 & 49.68 \\
\hline 15 March 2018 & 1.48 & 92.01 & 57.63 \\
\hline 16 March 2018 & 1.19 & 84.45 & 64.93 \\
\hline 17 March 2018 & 1.06 & 65.94 & 70.62 \\
\hline 18 March 2018 & 0.97 & 44.29 & 74.45 \\
\hline
\end{tabular}

A similar case, corresponding to the contributions to the El Burguillo reservoir (Figure 11), in the Alberche basin during the same episode in 2018, is shown below.

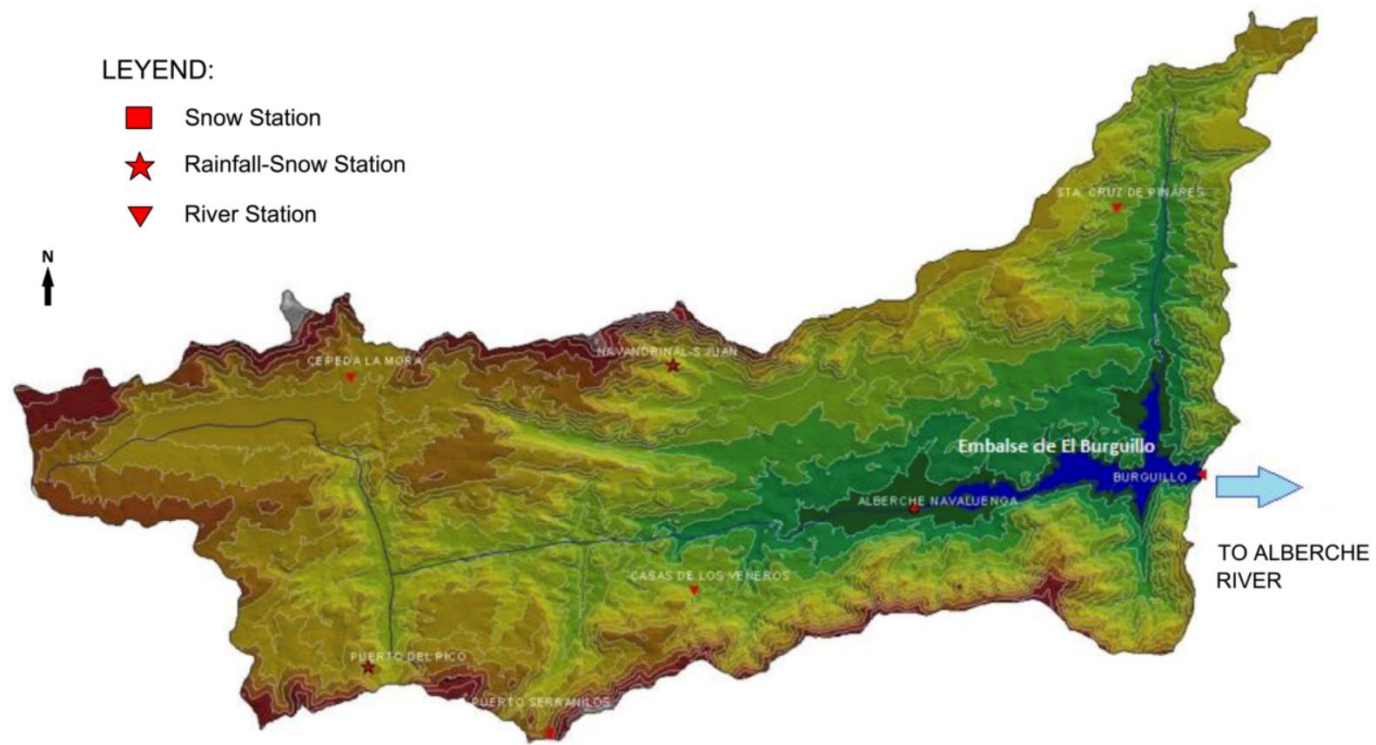

Figure 11. Location of the El Burguillo Reservoir in the upper part of the Alberche Basin. 
In Table 3, it can be seen that the storm produced a merger process of more than $13 \mathrm{hm}^{3}$ of Snow Water Volume (VAFN), previously accumulated between 8 March, 2018 and 18 March, 2018, which demonstrates the need to use hydrological models with a snow subroutine.

Table 3. Expected values of average daily flows, entering the El Burguillo reservoir from AEMET (most probable) temperature and rainfall predictions.

\begin{tabular}{|c|c|c|c|}
\hline $\begin{array}{c}\text { Date } \\
\text { (at 00:00 h.) }\end{array}$ & $\begin{array}{c}\text { Snow Water Volume } \\
\left(\mathrm{hm}^{3}\right)\end{array}$ & $\begin{array}{l}\text { Flow } \\
\left(\mathrm{m}^{3} / \mathrm{s}\right)\end{array}$ & $\begin{array}{c}\text { Accumulated Volume Inflow } \\
\qquad\left(\mathrm{hm}^{3}\right)\end{array}$ \\
\hline 8 March 2018 & 16.24 & & \\
\hline 9 March 2018 & 7.60 & 30.65 & 3.17 \\
\hline 10 March 2018 & 4.31 & 79.37 & 10.02 \\
\hline 11 March 2018 & 3.91 & 107.41 & 19.30 \\
\hline 12 March 2018 & 3.84 & 65.11 & 24.93 \\
\hline 13 March 2018 & 3.67 & 53.35 & 29.54 \\
\hline 14 March 2018 & 3.20 & 53.40 & 34.15 \\
\hline 15 March 2018 & 2.91 & 57.13 & 39.09 \\
\hline 16 March 2018 00:00 & 2.87 & 56.32 & 43.95 \\
\hline 17 March 2018 00:00 & 2.92 & 51.64 & 48.42 \\
\hline 18 March 2018 00:00 & 2.90 & 45.09 & 52.31 \\
\hline
\end{tabular}

As in the previous case of Tiétar (closure in the Rosarito reservoir), the storm before the episode that began on 9 March 2019, brought with it a large accumulation of snow in the basin (Figure 12). Its potential melt was considered in the calculation of future contributions to the El Burguillo reservoir. This gives consistency to the optimal management of reservoirs and their release that minimizes downstream damage without jeopardizing the safety of the dam or the guarantees of water supply.
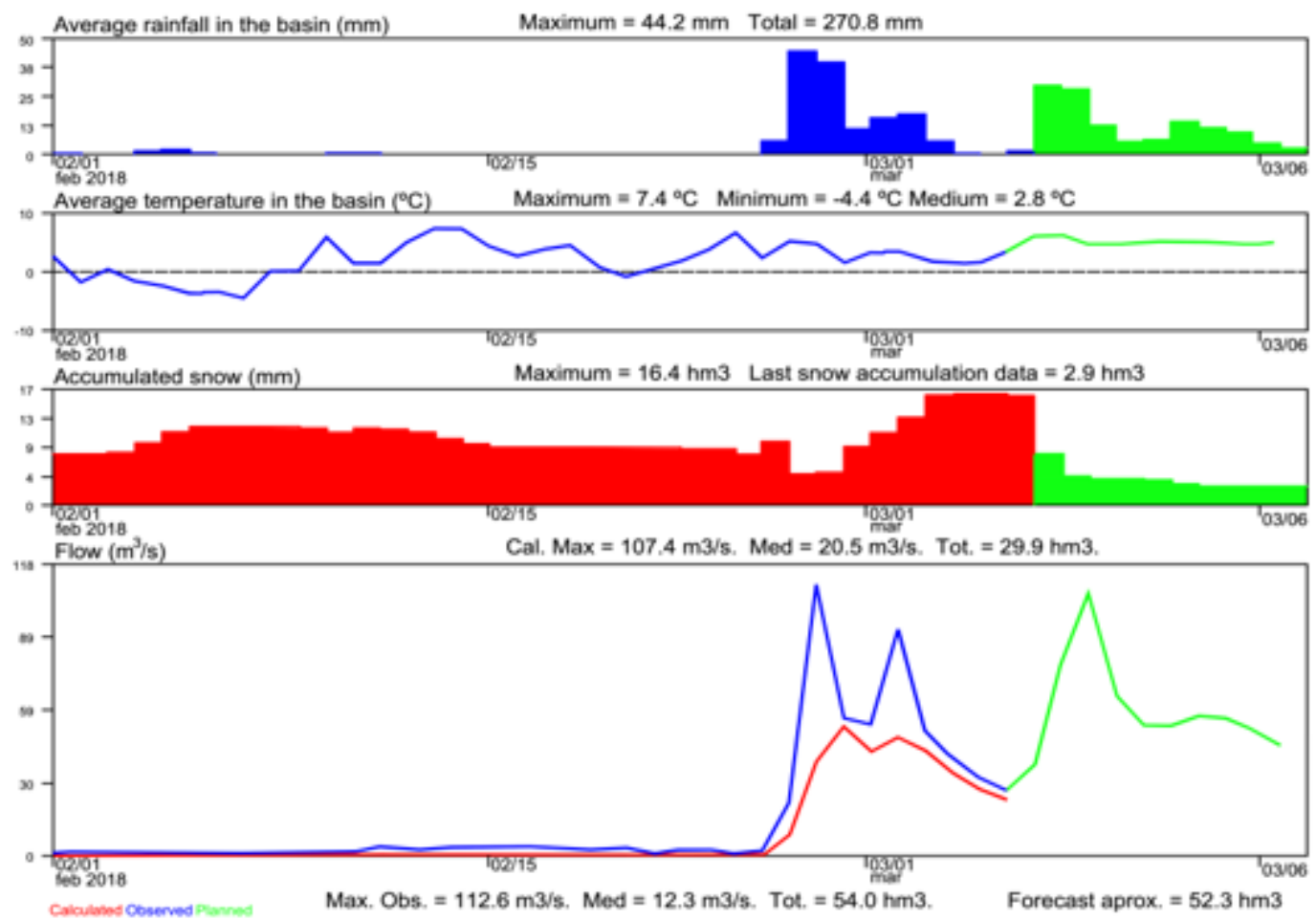

Figure 12. Flow forecast graph (green) in the El Burguillo reservoir, with the AEMET (most probable) temperature and rainfall predictions.

In both cases-Rosarito and El Burguillo-a very positive consequence can be obtained from the results achieved, since they have meant a notable advance with respect to the previous predictive methods, which could not take into account the additional flows generated by the snow layer fusion. 
The integrated SAIH-ASTER application of providing real time data to the ASTER model allowed for information on the accumulated snow reserves at the beginning of the episode to be obtained. This also helped to make a forecast of incoming flows in the El Burguillo reservoir. This forecast was calculated over time, using weather forecasts from AEMET. All this facilitated the management of the reservoirs and water release from the reservoir with the lowest possible flow peaks downstream.

\section{Conclusions}

Floods are among the most damaging natural disasters economically, but also causing serious disorder in human activity and endangering people's safety. Its effects are aggravated by anthropogenic intervention, through exposure to the risk of human transformation in the territory, and alteration of the natural regime of the rivers.

In the case of Spain, its special hydrological characteristics and the structure of water demand-with an important agricultural use that concentrates its consumption in the dry months-have promoted the construction of a significant number of dams to regulate its rivers. These infrastructures are an essential element for flood control and lamination. However, at the same time, they constitute a potential risk in the event of breakage due to overtopping, making it a priority to guarantee their safety.

The complex management of such a high number of hydraulic infrastructures has required the development of a technologically advanced Automatic Hydrological Information System (SAIH), which provides quasi-real-time data on the main hydrometeorological variables of the basin and dam hydraulics-information that facilitates the safe operation of reservoirs and establishing preventive safeguards during floods. However, the operation of reservoirs in mountainous areas, where the presence of snow is hydrologically significant, was not adequately resolved due to the lack of methods and tools to forecast inlet flows that took those resulting from melting snow layers into account.

The methodology developed by the Tajo Hydrographic Confederation integrates tools already available in the Hydrographic Confederations into the SAIH environment. This allows for the coupling of that system to supply input data to the ASTER hydrological modelling of the Water Snow Resources Assessment program (ERHIN). Thus, an appreciable improvement has been obtained in the forecasts of incoming flows in reservoirs of mountainous headwaters. The joint and coordinated application of SAIH and ERHIN has facilitated a more efficient use of resources and the means of both.

The data obtained as a result of the forecast are the inflows to the reservoir and the equivalent volume of water stored as snow in the watershed. These values help decision-making in real time (reservoir management), as its application by the Tajo Hydrographic Confederation has repeatedly demonstrated.

In the cases shown regarding the application of this process (Rosarito and El Burguillo reservoirs), it has been possible to verify the possibility of incorporating weather forecasts provided by the State Meteorological Agency (AEMET).

With this, it is possible to schedule, on time, preventive dam releasing and anticipate the implementation of more reliable safeguards.

The improvement of the described methodology and the generalization of its application to other hydrographic basins represent a great advance in the reduction in flood damage and improving the safety of dams located in mountainous areas.

Author Contributions: Conceptualization, I.M.P., J.A.H.M. and E.S.P.; Data curation, J.M.A.-M.; Formal analysis, J.M.A.-M.; Investigation, I.M.P. and J.M.A.-M.; Methodology, J.A.H.M. and J.M.A.-M.; Project administration, I.M.P.; Resources, J.A.H.M.; Validation, E.S.P.; Writing—original draft, I.M.P.; Writing—review \& editing, I.M.P. All authors have read and agreed to the published version of the manuscript.

Funding: This research received no external funding

Acknowledgments: Authors acknowledge support given by Tagus Hydrographic Confederation by providing detailed data.

Conflicts of Interest: The authors declare no conflict of interest. 


\section{References}

1. Consorcio de Compensación de Seguros. Estadística de Riesgos Extraordinarios Serie 1.971-2.017. Available online: www.consorseguros.es (accessed on 15 October 2019).

2. IPCC, W.G. AR5 Climate Change 2014: Impacts, Adaptation, and Vulnerability. 2014. Available online: https://www.ipcc.ch/report/ar5/wg2/ (accessed on 5 October 2019).

3. EC. circabc.europe.eu. Available online: https://circabc.europa.eu/webdav/CircaBC/env/wfd/Library/water directors/documents_presidency/meetingsdocuments/9\%20-\%20Best \%20Practices $\% 20 \mathrm{Flood} \% 20 \mathrm{final} \%$ 20version.pdf (accessed on 5 September 2019).

4. Comité Español de Grandes Presas SPANCOLD. Rotura de Presas. Análisis Estadístico, 1996; Comité Español de Grandes Presas SPANCOLD: Madrid, Spain, 1996.

5. Arenillas Parra, M.; Cobos Campos, G.; Navarro Caraballo, J. Datos sobre la Nieve y los Glaciares en las Cordilleras Españolas: El programa ERHIN 1984-2008; Monreal Teodoro, E., Francés Mahamud, M., Eds.; Ministerio de Medio Ambiente y Medio Rural y Marino: Madrid, Spain, 2008.

6. Available online: www.miteco.gob.es/es/cartografia-y-sig/ide/descargas/agua/saih.aspx (accessed on 10 September 2019).

7. Arenillas Parra, M.; Martínez Costa, R. El método Hidrológico-Estadístico. La Nieve en el Pirineo Español; MOPU: Madrid, Spain, 1988; pp. 99-126.

8. Anderson, E.A. National Weather Service river forecast system: Snow accumulation and ablation model (Vol. 17). In Technical Memorandum NWS Hydro-17; US Department of Commerce, National Oceanic and Atmospheric Administration, National Weather Service: Silver Spring, MD, USA, 1973.

9. Gioia, A.; Manfreda, S.; Iacobellis, V.; Fiorentino, M. Performance of a Theoretical Model for the Description of Water Balance and Runoff Dynamics in Southern Italy. J. Hydrol. Eng. 2014. [CrossRef]

10. Haggett, C. An integrated approach to flood forecasting and warning in England and Wales. J. Water Environ. Manag. 1998, 12, 425-432. [CrossRef]

11. Gioia, A.; Iacobellis, V.; Manfreda, S.; Fiorentino, M. Comparison of different methods describing the peak runoff contributing areas during floods. Hydrol. Process. 2017, 31, 2041-2049. [CrossRef]

12. Liu, J.; Han, D. On selection of the optimal data time interval for real-time hydrological forecasting. Hydrol. Earth Syst. Sci. 2013, 17, 3639-3659. [CrossRef]

13. Cantarino, I. Anuario Aster 98 UPV. 1998. Available online: http://www.upv.es/dit/ASTERanuario.html (accessed on 15 June 2019).

14. Morin, G.; Fortin, J.P.; Lardeau, J.P.; Sochanska, W. Modèle CEQUEAU: Manuel d'utilisation; INRS-Eau, Rapport Scientifique: Quebec, QC, Canada, 1981; p. 93.

15. Gascoin, S.; Hagolle, O.; Huc, M.J.; Dejoux, J.-F.; Szczypta, C.; Marti, R.; Sanchez, R. A snow cover climatology for the Pyrenees from MODIS snow products. Hydrol. Earth Syst. Sci. 2015, 19, 2337-2351. [CrossRef]

16. Arenillas, M.; Cobos, G.; Mora, J. El Programa ERHIN y la Gestión de Embalses en Áreas con Alta Precipitación Nival; Ingeniería Civil (144): Madrid, Sapin, 2006; pp. 89-96.

17. Cobos, G. Cuantificación de las Reservas Hídricas en Forma de Nieve y Previsión en Tiempo Real de los Caudales Fluyentes Derivados de la Fusión. Aplicación al Pirineo Español: Cuenca alta del río Aragón. Ph.D. Thesis, Universidad Politécnica de Valencia, Valencia, Spain, 2004.

18. Mora, J.; Ferrer, C.; Arenillas, M.; Cobos, G. Hydrological Peculiarities of Mountain Basins. The Case of the Spanish Pyrenees. In Proceedings of the International Conference on Water Observation and Information System for Decision Support, Ohrid, Macedonia, 25-29 May 2004.

19. Ferrer, C.; Romeo, R.; Arenillas, M.; Cobos, G. El Sistema ASTER-SAIH Aplicado a la Explotación de Embalses en Cuencas con Marcado Comportamiento Nival. In Proceedings of the VII Jornadas Españolas de Presas, Zaragoza, Spain, 29-31 May 2002.

(C) 2020 by the authors. Licensee MDPI, Basel, Switzerland. This article is an open access article distributed under the terms and conditions of the Creative Commons Attribution (CC BY) license (http://creativecommons.org/licenses/by/4.0/). 